\title{
The use of assistance flow by nurses to the patient with chest pain: facilities and difficulties
}

\author{
Utilização por enfermeiros do fluxo assistencial ao paciente com dor torácica: facilidades e dificuldades \\ Utilización por enfermeros del flujo asistencial al paciente con dolor torácico: facilidades y dificultades
}

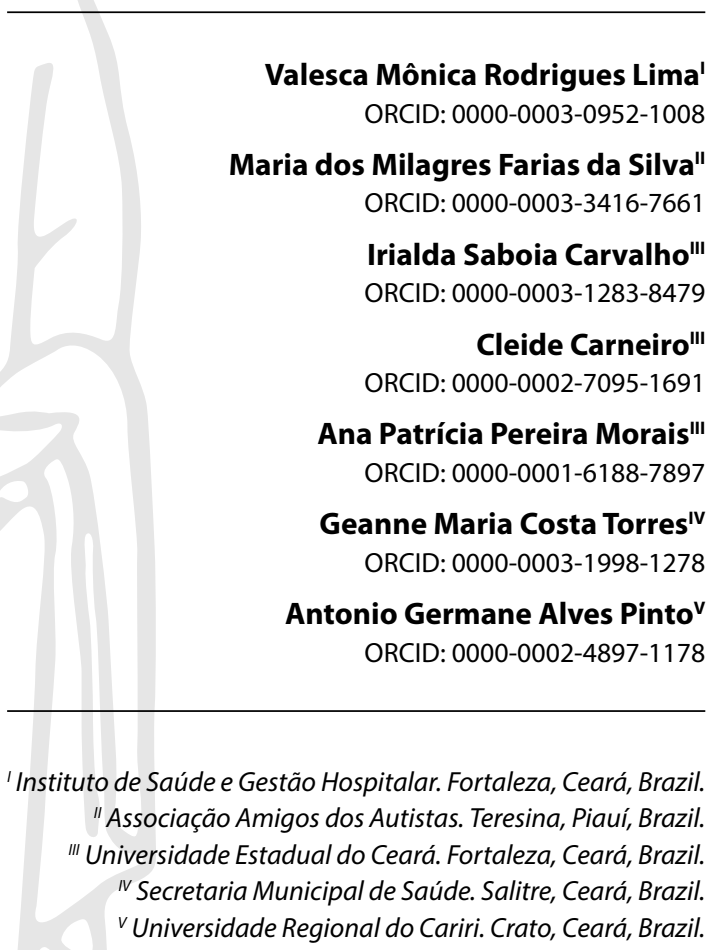

How to cite this article: Lima VMR, Silva MMF, Carvalho IS, Carneiro C, Morais APP, Torres GMC, et al. The use of assistance flow by nurses to the patient with chest pain: facilities and difficulties. RevBrasEnferm. 2021;74(2):e20190849. doi: http://dx.doi.org/10.1590/0034-7167-2019-0849

Corresponding author:

Geanne Maria Costa Torres

E-mail: gmctorres@hotmail.com

EDITOR IN CHIEF: Dulce Barbosa ASSOCIATE EDITOR: Mitzy Reichembach

Submission: $02-26-2020$

Approval: 09-16-2020

\section{ABSTRACT}

Objective: to analyze the facilities and difficulties in the use by nurses of the care flow for patients with chest pain. Methods: descriptive analytical study, with a qualitative approach, conducted with 17 nurses from an emergency care unit in a municipality of the State of Ceara, in 2018. Data collected through documents and interviews, analyzed in a descriptive manner, in absolute and relative frequencies and through content analysis thematic. Results: the use of assistance flow streamlines the process of transferring to referral units, reducing serious and lethal complications in the patient. It considers teamwork and communication as facilitating points in the care of patients with chest pain. The lack of permanent education, physical structure, equipment, transport delay and patient regulation as factors that hamper. Final considerations: investments in physical structure and equipment, in the reorganization of the care network and in permanent education to enable benefits to the service of excellence in health care.

Descriptors: Quality of Health Care; Chest Pain; Emergency Nursing; Myocardial Infarction; Education, Continuing.

\section{RESUMO}

Objetivo: Analisar as facilidades e dificuldades na utilização por enfermeiros do fluxo assistencial ao paciente com dor torácica. Métodos: Estudo analítico descritivo, com abordagem qualitativa, realizado com 17 enfermeiros de uma unidade de pronto atendimento de um município cearense, em 2018. Dados coletados por documentos e entrevistas, analisados de forma descritiva, em frequências absolutas e relativas e pela análise de conteúdo temática. Resultados: A utilização do fluxo assistencial agiliza o processo de transferência às unidades de referências, diminuindo complicações graves e letais no paciente. Consideram-se o trabalho em equipe e a comunicação como pontos facilitadores no atendimento ao paciente com dor torácica. Fatores dificultadores: a falta de educação permanente, estrutura física, equipamentos, atraso de transporte e regulação do paciente. Considerações finais: São necessários investimentos na estrutura física e equipamentos; reorganização da rede de atenção; e educação permanente para possibilitar benefícios ao serviço de excelência no cuidado em saúde.

Descritores: Qualidade da Assistência à Saúde; Dor Torácica; Enfermagem em Emergência; Infarto Agudo do Miocárdio; Educação Permanente.

\section{RESUMEN}

Objetivo: Analizar las facilidades y dificultades en la utilización por enfermeros del flujo asistencial al paciente con dolor torácico. Métodos: Estudio analítico descriptivo, con abordaje cualitativo, realizado con 17 enfermeros de unidad de atención de emergencia de Ceará, en 2018. Datos recogidos por documentos y entrevistas, analizados de forma descriptiva, en frecuencias absolutas y relativas y por análisis de contenido temático. Resultados: La utilización del flujo asistencial agiliza el proceso de transferencia a las unidades de referencias, disminuyendo complicaciones graves y letales en el paciente. Consideran el trabajo en equipo y la comunicación como puntos facilitadores en atención al paciente con dolor torácico. Factores dificultadores: la falta de educación permanente, estructura física, equipamientos, atraso de transporte y regulación del paciente. Consideraciones finales: Son necesarios inversiones en estructura física y equipamientos; reorganización de red de atención; y educación permanente para posibilitar beneficios al servicio de excelencia en el cuidado en salud.

Descriptores: Calidad de la Asistencia de Salud; Dolor Torácico; Enfermería en Emergencia; Infarto Agudo de Miocardio; Educación Permanente. 


\section{INTRODUCTION}

Healthcare in Urgency and Emergency is an important instrument for improving health in Brazil, highlighting the Emergency Care Units (UPA), operating 24 hours a day and aim at the concentration of services of intermediate complexity ${ }^{(1)}$. They offer simply structure such as radiography, electrocardiogram sections, pediatrics, exams laboratory, and observation beds. After attending and carrying out tests or procedures, it is analyzed the need to transfer the patient to a referral hospital or stay in the unit ${ }^{(2)}$.

At UPA, care is based on the welcoming model with risk classification, considering the protocols adapted by the Ministry of Health for each local reality, treating the patients by clinical severity based on their signs and symptoms, not on a first-come, first-served basis ${ }^{(3-4)}$. Risk classification is a tool that helps the nurse, by means of a qualified listening, to assume the role in regulating care demand and determining the priority of care for these patients, leaving these professionals to use protocols for the optimization and quality of care ${ }^{(5-6)}$.

In this context, the assistance protocols systematize the professional's action, serving as discriminators characterized as warning signs and symptoms, by means of a specific service and filed by a team trained for the situation ${ }^{(7)}$. Among the flowcharts used, there is an assistance flow for the chest pain, in order to precociously identify patients with acute myocardial infarction (AMI) ${ }^{(8)}$.

The acute thoracic pain is a very frequent symptom at emergency units, constituting a possible warning sign for diseases with imminent risk of death ${ }^{(9)}$. Although it seems easy, identifying a patient with such symptomatology is not simple, as the differential diagnosis made through exams, such as electrocardiogram (ECG), differs from the final diagnosis among the diseases that present such symptoms, becoming the critical point in the professionals' decision ${ }^{(7)}$.

In addition to acute coronary syndrome, due to their potentially fatal character, acute aortic dissection, pulmonary thromboembolism, hypertensive pneumothorax, cardiac tamponade, rupture and esophageal perforation stand out ${ }^{(9)}$. For this reason, the identification of severity in the classification must be quick, and the team must have knowledge and sensitivity to distinguish precordial pain from other pains ${ }^{(7)}$.

Thus, using a chest pain protocol, it is possible to understand the care efficiency not on a first come, first served basis, but by risk classification, including the situation of severity or life-threatening risk factors, directly collaborating for the reduction of morbidity and mortality ${ }^{(3,7)}$. The experiences in healthcare practice show that protocols favor actions sharing also focused on the responsibility, observation, and evaluating the processes in the service, providing significant contributions to the institutions ${ }^{(8)}$.

This way, the nursing professional tends to understand that a good assistance and an efficient care make all the difference for the patient, bringing benefits for a good recovery ${ }^{(10)}$. Then, being the nurse the main responsible for the risk classification, it is essential to be constantly trained, in relation to factors predisposing to coronary heart diseases and the distinction between the chest pain and another type of localized pain.

Under these aspects, observing the demands and services in a UPA in the city of Fortaleza, State of Ceara, it was noticed the use of assistance flow to patient with chest pain based on Manchester protocol, since the early care is a determinant factor for the therapeutic success. Accordingly, it is necessary to apply the protocol with scientific basis because clinic knowledge, sensitive listening of complaints and recognition of signs and symptoms related to AMI helps nurses' decision-making and contributes to the reduction of morbidity and mortality.

Then, recognizing the importance of this topic and emerging the interest for it within UPA service that receives patients with chest pain and AMI, which adopted a practice of using the protocol for the condition of significant improvements, as well as the awareness of professionals of the relevance of properly managing this technology, the desire to carry out this survey is justified. This is because it is cleared ${ }^{(11-12)}$ that the use of protocols facilitates the unification of care and adds quality of care by the health professionals, working as a guide for the professional, taking him to the path he wants to continue in the face of problems to be overcome, having it essential to reorganize the work process based on the problems experienced in these services.

For feeling anxious regarding the application of the chest pain flowchart, that is, for not feeling duly skilled in using this instrument, the importance of constant improvement of the work process of nurses in urgency/emergency services stands out, relying on permanent health education ${ }^{(13)}$. Therefore, nurses that classify the risk in everyday care need to continually improve their knowledge and skills in order to deliver classification and evaluation actions efficient and effective ${ }^{(8)}$.

Based on the above, the following questioning emerged: "What are the facilities/difficulties in the use of the flowchart for chest pain?"Therefore, once the correct and safe use of this assistance flow has been achieved, it will benefit the population that needs this healthcare, reducing the morbidity and mortality by $\mathrm{AMI}$ and providing a better quality of life.

\section{OBJECTIVE}

To analyze the facilities and difficulties in the use of the care flow by nurses for patients with chest pain

\section{METHODS}

\section{Ethic aspects}

The study was authorized by the Educational and Health Institutions, and approved by the Human Research Ethics Committee, in accordance with the Resolution No. 466/2012 of the National Health Council.

\section{Type of study}

Descriptive analytical study with a qualitative approach.

\section{Methodological procedures}

\section{Scenario of the study}

The survey was held at UPA Cristo Redentor (city of Fortaleza, State of (eara), which uses the Manchester protocol for risk classification of each patient. The survey venue was chosen because this unit is a pioneer in the implementation of assistance flow to patients with 
chest pain, being the only unit that has undergone an accreditation process granted by the National Accreditation Organization (ONA).

The capital of the State of Ceara is localized in the Northeast of Brazil and it is the fourth bigger city in the country. According to data from 2014 from the Brazilian Institute of Geography and Statistics (IBGE), the estimate population of Fortaleza was 2,571.896 inhabitants. Currently, for administrative purpose, the city is divided in seven Regional Executive Offices (SER) (I, II, III, IV, V, VI and Central).

The UPAs compose the urgency and emergency network of Fortaleza, providing adult and pediatric care. The chosen unit is localized in SER I. The neighborhood has 400,000 inhabitants in the west end of Fortaleza, where it started the Greater Fortaleza.

\section{Participants of the survey}

The study population was composed by nurses that work at UPA Cristo Redentor, using as inclusion criterion: work in assistance; and exclusion criterion: be on vacation and/or licensed, and work in nursing management. Soon, the trial was composed by 17 participants in a total of 2 nurses that worked for the Institution. From them, only one did not have risk classification course in Manchester screening protocol or Manchester screening system. In order to grant them the anonymity, they were designated by $\mathrm{Nr}$ (nurse), followed by an Arabic number, from 1 to 17 .

\section{Collect and organization of data}

The survey applied two techniques: documentary and semistructured interview. Initially, there was a meeting with the Institution Coordinator in order to explain the nature of the study and its purpose, as well as how to descriptively access the documents for consolidation of data from care provided to patient with AMI in the year of 2018.

For the interviews, it was used a semi-structured script with opened and closed questions, including questions regarding personal information, education, and professional experience, in addition to strengths and weaknesses in the use of assistance flow in service to a better understanding of the object under study.

Meetings were held from November to December 2018 in a reserved room, made available by the Institution. They were previously scheduled to happen during duty, according to work schedule of each participant, and individually, in order they could express in privacy.

As professionals became available to participate in the survey without prejudice to their activities, the interviews were initiated by a single surveyor, and registered in a digital recorder, lasting around 10 minutes. Then, they were entirely transcribed by the interviewer himself.

\section{Data analysis}

For the analysis of documentary data, a descriptive analysis was performed, in absolute and relative frequencies. Qualitative data produced by the interviews were analyzed according to the thematic content proposed by Minayo ${ }^{(14)}$, which unfolds in the pre-analysis stages, exploration of the material or codification and treatment of the obtained results/interpretation.

In pre-analysis, after organization of all material collected, floating readings were performed, repeatedly, to go deeper into the content and observation of hypotheses, as well to obtain a more consistent comprehension in their exploration and peculiarities.

Then, the material was explored for the constitution of corpus, taking in consideration words, sentences, and significant expressions, with interpretation of the speeches by approximation and reflection on the contents, making it possible to apprehend a vision of the whole, differences and convergences, decomposing the data and making a relation among the parties. Therefore, three categories emerged: Category 1 - Evaluation of assistance flow of chest pain; Category 2 - Facilities found in the care of patients with chest pain; Category 3 - Difficulties noticed during the risk classification flow.

The last stage (processing of the results obtained and their interpretation) culminated in a reflective analysis, using a pertinent literature and comparing the results both with other survey pertinent to the topic under study and with our perceptions and reflections.

\section{RESULTS}

\section{Profile of the respondents}

From the 17 participating nurses of the survey, female gender prevailed $(16 ; 94.12 \%)$, with ages ranging between 31 and 40 years old $(9 ; 52.94 \%)$, having 4 to 10 years of graduation. Of these, 9 (52.94\%) graduated from public education.

When inquired about the formative processes after graduation, 16 $(94,12 \%)$ reported that completed some postgraduate course, reflecting that there is a continuity in the training process and a concern with professional qualification. Analyzing the post-graduation area, there are various specializations in the field of nursing, with a greater emphasis on the choice in the area of Pediatric and Neonatal ICU/ Nursing in the Intensive Care Unit (8;50\%), with time of professional activity varying from 6 to 15 years average, with emphasis on the performance of some professionals as nursing technicians, before graduation. All respondents worked in the hospital system and in the intermediate health unit as assistance nurses.

\section{Category 1: Evaluation of assistance flow of chest pain}

When evaluating the daily practice on the diagnostic screening of the chest pain in UPA patients, the respondents used the word "life" in the sense of a vital act in the care assistance, objectively impacting on a better prognosis of his clinical condition.

In addition, we can find affirmations that, when they come across a possible AMI, and when apply correctly the protocol, they act with resoluteness, and in due time forward the patient to the reference centers, as described in the following statements:

levaluate the flow as very useful, [...] "save many lives"; I've done many chest pain flows, 'I have already taken many patients with segment elevation myocardial infarction", and all of them were transferred alive to be able to do the procedure in a referral hospital. (Nr 1)

In my opinion, it is an excellent job! [...] that really worked here at UPA... that patients with supra [electrocardiogram with elevation of the ST segment in two or more parts at least] are transferred to the Hospital in Messejana. It is a protocol that, if you follow it strictly, you will have good results. (Nr 5) 
It's something that is not only in the paper [...] it really has a dynamic, it works in a correct time. I'm really glad to see the resolution of this protocol! [...]. What we have known is that many lives were saved, showing that this protocol, undoubtedly, is highly effective in the reduction of damages and death of patients. ( $\mathrm{Nr} 7)$

Super positive! Firstly, because we follow this pattern [...] this flowchart that is the AMI protocol, and it has saved many lives and early identified cardiovascular problems or segment elevation myocardial infarction. ( $\mathrm{Nr} 13$ )

Therefore, it was evident that the classifier nurses believe that the evaluations of the AMI protocol can meet the demand at UPA and, consequently, there is a positive co-relation between the identified cases and the transfer process to referral units in a timely manner, decreasing the chances of more serious and lethal complications to the patient.

\section{Category 2: Facilities found in the care of patients with chest pain}

Among the elements of the work process that contribute to increase the diagnosis by means of the flowchart of chest pain performed by nurses, the team engagement, the use of mobile applications for communication, number of equipment, and suitable physic structure were notably reported in their speeches:

Today, we don't depend only on the radio [...] as we add an application on the cellphone to call the administrative section and the chief of the team... "Well, I think it's perfect". (Nr 3)

Since from the beginning, I believed that AMI protocol was a great solution [...] we, today, here at the unit, have two electrocardiogram equipment. We have the red room and one equipment exclusive in there. ( $\mathrm{Nr}$ 9)

All the professionals know how the flow works, since the receptionist until the nurse that classifies the risk. (Nr 10)

The physical structure and the number of equipment were mentioned by the classifier nurses as important aspects for the care developed at UPA. The provision of an appropriate environment for screening and classification, equipped with an ECG and used in an exclusive way, shorten the waiting time between the conduction of the exam and the diagnostic.

The assistance at UPA has facilities when developing its assistance actions, with the team's work and commitment to achieving common goals being positively highlighted, a fact that gained prominence in the voices of these professionals:

The professionals, since the reception and concierge, are all oriented and engaged. ( $\mathrm{Nr}$ 01)

We see everybody in the team working together, as really a team! United [...] it evolves since the reception until the patient get to the doctor. When the patient arrives at the reception, they advise us that he/she has the hand in the chest [...] so all the team interacts, and the interaction of all the team is a positive aspect. ( $\mathrm{Nr} 17)$

\section{Category 3: Difficulties noticed during the risk classifica- tion flow}

The weaknesses in service dynamics within the UPA are related to the need to expand the physical structure, equipment, human resources, delay in external transport and patient regulation, in order to optimize and prioritize patient care, as it is highlighted in the following speeches:

I believe it should have a specific ambulance for this type of patient [...] that could already start measurements and administrate the medications, it would speed up more, because the patient is seen but, sometimes, he stays here because there is no ambulance or a better transportation. Barriers are still found in relation to the external transportation of patients, regarding regulation and SAMU, attributed to the macro system. (Nr 4)

I think that, if we had a room dedicated, it would be good for carrying out the protocol [...]

Because sometimes the patient takes the ECG and then stops because there is a patient in the red room, and we don't have our own cart, we take a little while to assist the patient. (Nr 5)

Once, a patient with epigastric pain was having an infarction. So, [...] it doesn't mean a failure when applying the protocol, but what we could do in a better way, for example, we just need to better understand the patient's complaint, to add the flow, it's a suggestion, an analysis. ( $\mathrm{Nr} 8$ )

When the patient doesn't walk, it's necessary a wheelchair [...] and it's not possible at that moment. (Nr 13)

The only negative aspect / see is related to the ECG equipment [...] where it is. The ECG issue of sometimes having it in the red room and sometimes not having the equipment itself, we usually make the exam in the medication room, where the equipment is, but it should be used in the red room. When it is in the red room, we use it there. It's a negative aspect to be improved. (Nr 17)

According to the reports, there are obstacles in the quality of the service provided, the quantity of equipment for the exams, the lack of a wheelchair, affecting the reception of patients with reduced or total mobility; the difficulties in transferring the patient to a referral hospital is also mentioned.

Still, in an individual way, we can notice difficulties when interpreting a diagnostic exam, as mentioned by $\mathrm{Nr} 4$ :

The flow, as I said, is very clear. But there are still breaches, due to [...] the existing gaps regarding our education as nurses, regarding our knowledge about electrocardiogram. ( $\mathrm{Nr} 4)$

According to the established dialogues, it is noticed the precariousness in training and updating of nurses regarding the knowledge related to cardiac physiology, as well as the reading and interpretation of the ECG equipment. It shows the need for continuous practices of permanent education in urgency and emergency services, considering that the curriculum for health education do not yet address this level of care. 


\section{DISCUSSION}

The creation of chest pain units, recognized as a new configuration for emergency assistance, improve the classification of patients that present chest pain or any other symptom suggestive of acute coronary syndrome, through the use of specific protocols as well as organized algorithms, also called "clinical decision trees", for better therapeutic strategy ${ }^{(15-16)}$.

Based on this premise, it highlights the importance of the involvement of the health team in the quick identification and performance of the chest pain flowchart, for an appropriate approach and a correct diagnostic, in order to initially rule out other pathologies that compromise the life of the patient ${ }^{(17)}$. Another study developed in the municipality of Fortaleza-CE regarding the quality of assistance care delivered to patients with chest pain in a referral hospital unit, shows that 281 (71.6\%) professionals claimed that the most part of health problems detected was solved ${ }^{(18)}$.

At UPA under study, it is used the assistance flow to the patient with chest pain in order to early identify patients with IMA. Of a total of 61 patients seen and that had the institution protocols, only $1(1,63 \%)$ died, in 2018 . The others were transferred to the referral unit. Therefore, it shows the low mortality rate for the year in question, by the effectiveness of the flowchart in action, providing quickness and safety in service and proper conduct. This fact contradicts other studies that demonstrated a high rate ${ }^{(19)}$ of deaths when examining the profile of patients seen in the red room of a 24-hour emergency unit, with a percentage of $44 \%$ of deaths compared to other units.

Regarding the evaluation of the flow of assistance to patients with chest pain, a survey conducted with a nursing team about the implantation and execution of the Manchester protocol in a UPA, revealed that all the 14 respondents ${ }^{(20)}$ reaffirmed the implantation and acceptance of the protocol by the nursing teams as a positive factor, with improvement in the work process. In this sense,

Nurses have a fundamental role in assisting infarcted patients, implementing actions in order to identify problems, causes and risks, deploying their skills and ensuring effective attention in the search or control of problems, preventing or delaying injuries, making their manager role with his team and other health professionals, coordinating the approach taken. To carry out these activities, up-to-date knowledge is needed to provide security and skills in the application of this vital care provided to cardiac patients ${ }^{(18)}$.

Therefore, emergency care needs to be supported at all levels of care, each within its limitations of resolvability. For this, the effective communication among Basic Attention, UPA, Emergency Mobile Care Service (SAMU), hospitals, becomes essential for the efficiency of the service ${ }^{(21)}$. Such situation allows us to understand that the work process of the respondents occurs in a work environment that favors the participation of the aligned management with processes and flows, committed to the best quality and provision of services to users. Therefore, the protocol for AMI can classify and detects early cases of chest pain, allowing the classifier nurse a greater support, since it uses very objective criteria.

The assistance provided by nurses highlights the facilitating character of the services offered by UPA, through the strengthening of the mechanisms of the assistance organization, such as the Manchester protocols, team engagement, effective communication, and other factors that provide an immediate conduct from the initial evaluation of the patient, contributing to the prevention of complications related to the identified risk factors. Therefore,

Nurses are the professionals responsible for the emergency service screening, it is up to them evaluate the patient, determine priority needs and refer him to the treatment area; emergency care in hospital units has an important role in the recovery and maintenance of the individual's health, with the early identification of a possible infarction and the acceleration of care as a primary factor to decrease the time of heart muscle suffering ${ }^{(22)}$.

In order the risk classification to occur efficient and effectively, it is necessary that all nurses are qualified and trained, intending to identify the risk conditions ${ }^{(23)}$ that users are going through to indicate the degree of urgency, and having in mind that the training has to be permanent and in accordance with the institution. In a survey shared with nurses from a UPA from Florianopolis-SC, some professionals mentioned facilitators for their insertion in service, such as a good receptiveness ${ }^{(21)}$ by those who already worked there, a previous professional experience with urgencies, and specialization in urgency before joining UPA. Based upon this premise,

For teamwork happen, collaboration among its members is necessary, that there is an exchange among different knowledge. It also presupposes relationships that promote collaboration and communication in order to contribute to the development of work, based on dialog and horizontal relations ${ }^{(24)}$.

Other study findings accomplished with nurses in a University hospital in Spain recognize the need ${ }^{(21,25)}$ of the teamwork, and the importance of quality of health education offered to the patient. However, speeches denote difficulties in team working, such as individualism, high turnover of employees, lack of autonomy and stimulus to the teams.

There are still difficulties found in the risk classification sector, such as the lack of knowledge of society, high demand, precariousness of the public sector, insufficient resources and number of professionals, lack of physical structure, hospital facilities and equipment, in addition to failures in service management (26). Nurses of the study in question reiterated that difficulties found during the classification by the chest pain flowchart, and identification of AMI cause tension and generates discomfort in the multi-professional team.

The lack of agreement between services also shows as a complicating factor in work process, affecting the effectiveness of the referral system, as well as the lack of structuring of the urgency and emergency network in the municipalities ${ }^{(27)}$. Another survey points that there are some obstacles in providing qualified assistance, such as: lack of available beds, lack of basic material and human resources, in addition to the necessity of courses or programs for technical and scientific improvement of employees, in order to offer a fast, effective, and efficient assistance to the patient ${ }^{(28)}$.

The importance of training on service becomes substantial, in view of complicating factor in interpreting ECG by the 
respondents. This fact is reinforced in a study carried out with nurses from an Intensive Care Unit and Cardiology Unit of a teaching hospital in the city of Recife, State of Pernambuco, which reported that knowledge of nurses investigated regarding theoretical and practical aspects of ECG needs deepening ${ }^{(29)}$. For excellence in the work, it is necessary to expand new knowledge for decision-making in emergency services, as chest pain units need agile, efficient and qualified professionals to systematize the diagnostic and therapeutic strategies in the first patient care with cardiovascular problems.

In this sense, the lack of domain and justification by the nurse to approach the patient with chest pain, during the classification of severity, tends to delay the therapeutic care. ${ }^{(15)}$. Thus, when a team is trained, qualified, and motivated, service is carried out in a quick way generating, consequently, a suitable and qualified care to the patient ${ }^{(16)}$. Permanent education in health, when implemented in urgency and emergency services, favors the development of abilities and skills that imply the provision of an excellent service in comprehensive healthcare.

Surveys point to the reduction of coronary events in situations in which acute coronary syndrome is treated effectively, by means of protocols and attendance, making important that the professionals involved are trained to develop the management of cardiovascular emergencies ${ }^{(6)}$. The use of this instrument for chest pain is a guide for the promotion of evaluation and effective and quickly handling, upon a safer attention, recognizing the value of the nurse's work, for carrying out the actions related to the protocol, as this is the professional ${ }^{(30)}$ who makes the first contact, and needs to show abilities to develop the actions in a proficient, scientific, human, and ethic way.

It is evident in this survey, the importance of the use of assistance flow to the patient with chest pain performed by the nurse, and it is essential for the improvement in the work process and for "saving many lives". We conclude, then, that Manchester protocol is a relevant instrument, attached to the care with risk classification, which allows quick service, and effectiveness of care, by means of consistent criteria of classification proven by the nurse that assist the patient. Points showed as facilities and difficulties during the assistance flow, mentioned by the respondents, are related to the teamwork, communication, availability of equipment, physical structure, permanent education, delay in transportation, and regulation of patient.

\section{Study limitations}

As it is a service with structural and operational parameters found in throughout Brazilian territory, reproducibility of the findings can be diversified depending on the health management policies and practices of each unit. Thus, the experience analyzed by this manuscript is delimited by the need to express, in practice, how the flow and daily care occurs, without universal measurements of these results.

\section{Contributions to the Area}

The study allowed us to understand the aspects that evolve the effectiveness of the chest pain flowchart sequence in nursing practice. This assistance flow is considered as something effective, efficient, and directly impacts the improvement of health quality of the patients, in addition to the promotion of safety for the professional in the initial care, minimizing the risks of adverse events, as services that do not use this tool may elevate the risk of mistakes.

\section{FINAL CONSIDERATIONS}

This survey made it possible to understand the evaluation of the assistance flow to patients with chest pain from the perspective of professional nurses and their praxis in an emergency care unit in the city of Fortaleza. Regarding the evaluations of the assistance flow specific to the patient with pain complaint, usually, the respondents recognize the importance of the use of the protocol as a crucial tool to early identify the patient with acute myocardial infarction.

The use of the protocols emerges as a health technology tool aiming to substantiate scientifically the practices of the professionals, since the measures' standardization based in scientific evidence prevent error in the identification of the medical and nursing diagnosis, decreasing the occurrence of adverse events and damages to the patient.

Nurses reported positive aspects that prevailed over the negative faced in their care practice, which are: team engagement, use of mobile applications for communication, number of equipment, appropriate physical structure. They also believe they act in an effective way. However, some speeches report the need for simple adaptations in physical structure, such as a specific room for treatment of chest pain, as these patients are assisted in the same room used for emergency patients in general. Other issues found were the shortage of human resources, delay in external transportation, regulation of patients, and permanent education.

Therefore, the study made it possible to recognize that the flowchart used in this emergency care unit contemplates the need of professionals, as well as the local reality of the population in which this service is inserted. Thus, once the correct and safe use of the assistance flow to patients with chest pain is reached, it will benefit the population that needs this healthcare.

\section{REFERENCES}

1. Ministério da Saúde (BR). Ações e Programas. Unidade de Pronto Atendimento (UPA 24 h) [Internet]. 2017 [cited 2018 Dec 18]. Available from: http://portalms.saude.gov.br/acoes-e-programas/upa/sobre-o-programa

2. Conselho Nacional de Secretários de Saúde (BR). Rede de Atenção às Urgências e Emergências: Avaliação da Implantação e do Desempenho das Unidades de Pronto Atendimento (UPA) [Internet]. 2015 [cited 2018 Dec 18]. Available from: https://www.conass.org.br/biblioteca/pdf/ Conass_Documenta_28.pdf 
3. Souza CC, Araújo FA, Chianca TCM. Produção científica sobre a validade e confiabilidade do Manchester: revisão integrativa da literatura. Rev Esc Enferm Usp. 2015;49(1):144-51. https://doi.org/10.1590/S0080-623420150000100019

4. Duro CLM, Lima MADS, Levandovski PF, Bohn MLS, Abreu KP. Percepção de enfermeiros sobre a classificação de risco em unidades de pronto atendimento. Rev Rene. 2014;15(3):447-54. https://doi.org/10.15253/2175-6783.2014000300009

5. Hermida PMV, Nascimento ERP, Echevarría-Guanilo ME, Brüggemann OM, Malfussi LBH. Acolhimento com classificação de risco em unidade de pronto atendimento: estudo avaliativo. Rev Esc Enferm Usp. 2018;52: e03318. https://doi.org/10.1590/s1980-220x2017001303318

6. Farias MM, Moreira DM. Impacto de protocolo de dor torácica sobre a adesão às diretrizes societárias: um ensaio clínico. Rev Bras Cardiol [Internet]. 2012 [cited 2020 May 1];25(5):368-76. Available from: http://www.onlineijcs.org/english/sumario/25/pdf/v25n5a04.pdf

7. Vieira AC, Bertoncello KCG, Girondi JBR, Nascimento ERP, Hammerschmidt KSA, Zeferinho MT. Percepção dos enfermeiros de emergência na utilização de um protocolo para avaliação da dor torácica. Texto Contexto Enferm[Internet]. 2016 [cited 2019 Oct 18];25(1):1-7. Available from: http://www.scielo.br/pdf/tce/v25n1/pt_0104-0707-tce-25-01-1830014.pdf

8. Oliveira GMM, Villela PB. A importância da fase pré-hospitalar no infarto do miocárdio com supradesnivelamento de ST. Arq Bras Cardiol. 2018;111(4):594-5. https://doi.org/10.5935/abc.20180209

9. Santos ES, Timerman A. Chest pain in the emergency room: who is left and who can be released? Rev Soc Cardiol [Internet]. 2018 [cited 2020 May 1];28(4):394-402. Available from: https://pesquisa.bvsalud.org/portal/resource/pt/biblio-970499

10. Ribeiro KRA, Silva LP, Lima MLS. Conhecimento do infarto agudo do miocárdio: implicações para assistência de enfermagem. Rev Enferm UFPI [Internet]. 2016 [cited 2020 May 1];5(4):63-8. Available from: https://pesquisa.bvsalud.org/portal/resource/pt/bde-31858

11. Rabello A, Garcia ACP, Lima RCD, Fioroti CEA. Acolhimento e a Classificação de Risco: possibilidades e desafios para a acessibilidade em um serviço de urgência. Rev Bras Pesqui Saúde [Internet]. 2018 [cited 2019 Dec 01];20(1):49-58. Available from: http://www.periodicos.ufes.br/ RBPS/article/download/20608/13853

12. Scolari GAS, Rissardo LK, Baldissera VDA, Carreira L. Emergency care units and dimensions of accessibility to health care for the elderly. Rev Bras Enferm. 2018;71(suppl2):811-7. https://doi.org/10.1590/0034-7167-2017-0440

13. Alves PMB, Oliveira CR, Sampaio SPAF, Oliveira KR. Identificação do tratamento mais eficaz na Síndrome Coronariana Aguda na Unidade de Terapia Intensiva: revisão bibliográfica. Rev Amazônia: Sci Health. 2017;5(3):37-41. https://doi.org/10.18606/2318-1419/amazonia.sci.health. v5n3p37-41

14. Minayo MCS. O desafio do conhecimento: pesquisa qualitativa em saúde. São Paulo: Hucitec; 2014. 408p.

15. Bassan R, Pimenta L, Leães PE, Timerman A. Sociedade Brasileira de Cardiologia. I Diretriz de dor torácica na sala de emergência: definição de graus de recomendação e níveis de evidência [Internet]. 2002 [cited 2019 Dec 01];76(supl II):1-22. Available from: http://publicacoes. cardiol.br/consenso/2002/7903/Toracica.pdf

16. Silva GM, Seiffert OMLB. Educação continuada em enfermagem: uma proposta metodológica. Rev Bras Enferm. 2009;62(3):362-6. https:// doi.org/10.1590/S0034-71672009000300005

17. Bañol-Betancur Jl, Martínez-Sánchez LM, Rodríguez-Gázquez MA, Bahamonde-Olaya E, Gutiérrez-Tamayo AM, Jaramillo-Jaramillo LI, et al. Caracterización del dolor torácico en pacientes que consultan al Servicio de Urgencias de una institución de salud de alto nivel de complejidad, en el periodo 2014-2015, en Medellín, Colombia. Rev Soc Espanhola Dor. 2017;24(6):288-293. https://doi.org/10.20986/ resed.2017.3571/2017

18. Leite ACS, Nogueira AO, Farias LGO. Qualidade da assistência à pacientes com dor torácica aguda no estado do Ceará, Brasil. Rev Dor. 2017;18(2):103-07. https://doi.org/10.5935/1806-0013.20170021

19. Soares TCS, Marta CB, Silva RCL, Peregrino AAF, Santiago LC, Schutz V. Perfil dos usuários atendidos na sala vermelha de uma unidade de pronto atendimento 24h. Rev Enferm UFPE. 2016;10(12):4619-27. https://doi.org/10.5205/reuol.9978-88449-6-ED1012201625

20. Fundão LP, Gotardo NMJ, Endlich RF. The perception of the nurse face the implentation and enforcement of the protocol of manchester in a unit of the city of service ready Guarapari-ES. Rev Científ Faesa. 2016;10(1):102-09. https://doi.org/10.5008/1809.7367.075

21. Oliveira SN, Ramos BJ, Piazza M, Prado ML, Reibnitz KS, Souza AC. Unidade de Pronto Atendimento - UPA 24h: percepção da enfermagem. Texto Contexto Enferm. 2015;24(1):238-44. https://doi.org/10.1590/0104-07072015003390011

22. Teixeira AFJ, Franco A, Castanharo J, Oliveira KCS. Atuação da equipe de enfermagem no atendimento de emergência ao paciente com infarto agudo do miocárdio. Rev Cienc Enferm [Internet]. 2015 [cited 2019 Oct 10];8(1):300-09. Available from: http://unifafibe.com.br/ revistasonline/arquivos/revistafafibeonline/sumario/36/30102015185545.pdf

23. Dias SRS, Silva IA, Santos LL. Risk classification at urgency and emergency services: integrative literature review. Rev Enferm UFPI [Internet]. 2018 [cited 2019 May 27];7(1):57-62. Available from: https://revistas.ufpi.br/index.php/reufpi/article/view/6712

24. Silva SEM, Moreira MCN. Equipe de saúde: negociações e limites da autonomia, pertencimento e reconhecimento do outro. Ciênc Saúde Coletiva. 2015;20(10):3033-42. https://doi.org/10.1590/1413-812320152010.20622014

25. Thofehrn MB, López Montesinos MJ, Amestoy SC, Porto AR, Bettin AC, Fernandes HN, et al. Trabalho em equipe: visão de enfermeiros de um hospital de Murcia/Espanha. Enferm Glob [Internet]. 2014 [cited 2019 May 27];36(13):338-51. Available from: http://scielo.isciii.es/pdf/eg/ v13n36/pt_administracion3.pdf

26. Nascimento ERP, Hilsendeger BR, Neth C, Belaver GM, Bertoncello KCG. Classificação de risco na emergência: avaliação da equipe de enfermagem. Rev Enferm UERJ[Internet]. 2011 [cited 2019 May 27];19(1):84-8. Available from: http://www.facenf.uerj.br/v19n1/v19n1a14.pdf 
27. O'Dwyer G. A gestão da atenção às urgências e o protagonismo federal. Ciênc Saúde Coletiva. 2010;15(5):2395-240. https://doi.org/10.1590/ S1413-81232010000500014

28. Silva FO, Silva WM, Fernandes GCG. Percepção do enfermeiro sobre o atendimento ao paciente com suspeita de infarto agudo do miocárdio. Ensaios USF [Internet]. 2017 [cited 2019 Dec 01];2(1):1-13. Available from: http://ensaios.usf.edu.br/ensaios/article/view/16

29. Fernandes, LS, Lira MCLS, França VV, Valois AA, Valença MP. Conhecimento teórico-prático de enfermeiras sobre eletrocardiograma. Rev Baiana Enferm. 2015;29(2):98-105. https://doi.org/10.18471/rbe.v29i2.12654

30. Caveião C, Hely AP, Montezeli JH, Barros APMM, Sordi JA, Santos SC. Desafios ao Enfermeiro na Implantação da Classificação de Risco em Unidade Mista. Rev Enferm UFSM. 2014;4(1):189-96. https://doi.org/10.5902/2179769210527 